\section{Using Processed Corn Stover as an Alternative to Peat}

\author{
Sabrina J. Ruis ${ }^{1}$, Humberto Blanco-Canqui, and Ellen T. Paparozzi \\ University of Nebraska-Lincoln, Department Agronomy and Horticulture, \\ Lincoln, NE
}

Russ Zeeck

Pellet Technology USA, LLC, Gretna, NE

Additional index words. tomato, marigold, greenhouse mix

\begin{abstract}
Processed corn (Zea mays L.) stover (PCS), defined as finely ground stover with or without additions, could be a potential alternative to peat in greenhouse mixes. However, this option has not yet been examined. We performed two split-plot experiments (1 and 2) with tomatoes (Solanum lycopersicum L.) and marigolds (Tagetes patula L.) as main plots. Expt. 1 involved five stover rates $(0 \%, 25 \%, 50 \%, 75 \%$, and $100 \%$ by volume) mixed with peat as subplots. Expt. 2 involved $0 \%$ stover mixed with peat, $25 \%$ distillers grain, and $50 \%$ quick compost (mechanically processed to accelerate compost process) stover with and without $\mathrm{CaO}$, and $75 \%$ quick compost stover without $\mathrm{CaO}$, as subplots. We measured growth parameters (height, dry weight, and flower number) and properties of the mixes. During Expt. 1, across both species, the addition of stover at rates $>\mathbf{5 0} \%$ reduced relative greenness by $\mathbf{4 0 \%}$, vegetative biomass yield by $\mathbf{7 4 \%}$, and reproductive biomass yield by $73 \%$ compared to mixes with $0 \%$ and $25 \%$ stover. As the stover rate increased, available water content in the mixes decreased $(r=$ $-0.34 ; P<0.001)$. Mixes with $0 \%$ and $25 \%$ stover had $34 \%$ more available water than mixes with $100 \%$ stover, which probably reduced plant growth in the $100 \%$ stover treatment. As the stover rate increased, plant tissue $\mathbf{N}$ and $\mathbf{P}$ concentrations decreased. Mixes with $0 \%$ stover generally had greater $\mathbf{N}$ and $\mathbf{P}$ concentrations than mixes with stover. During Expt. 2, for marigolds, the addition of $50 \%$ quick compost stover+CaO and $75 \%$ quick compost stover-CaO reduced relative greenness by $19 \%$ and vegetative biomass by $66 \%$ compared to mixes with $25 \%$ distillers grain or $0 \%$ stover. For tomatoes, the addition of $50 \%$ quick compost stover+ $\mathrm{CaO}$ and $75 \%$ quick compost stover-CaO reduced biomass yield by $64 \%$, which may be due to the higher $\mathrm{pH}$ and electrical conductivity (EC) of both treatments. Plant tissue $N$ and $P$ concentrations were greater in the mix with $25 \%$ distillers grain compared to most treatments, but $N$ and $P$ concentrations in the other mixes varied. Overall, the $25 \%$ distillers grain (3 peat: 1 distiller grain: 4 perlite) and $25 \%$ stover ( 3 peat: 1 stover: 4 perlite) treatments showed the most promise as additives in a peat-based mix.
\end{abstract}

Soilless mixes that include components of peat, perlite, vermiculite, and other organic materials are commonly used in the greenhouse industry (Barrett et al., 2016; Vaughn et al., 2011). The most common organic component of soilless mixes is peat because of its high water-holding capacity, high porosity, low bulk density, high nutrient exchange capacity, and relatively widespread availability (Barrett et al., 2016; Vaughn et al., 2011). Peat may be composed of many different plant materials, and it is formed through partial decomposition of these plant materials under waterlogged conditions in wetland environments. These peat-forming wetlands comprise a small portion of the Earth's land surface, $\approx 3 \%$, but contain an

Received for publication 10 Aug. 2018. Accepted for publication 13 Dec. 2018.

We would like to acknowledge the assistance of Kelsey Karni and Walter Stroup from the Statistics Consulting Team at University of Nebraska-Lincoln for their assistance in the statistical analysis of this manuscript.

${ }^{1}$ Corresponding author. E-mail: sruis2@unl.edu.

peat after draining (Alvarez et al., 2017), fluctuating water levels (Juckers and Watmough, 2014), and plant community shifts due to fluctuations in climate (Schwarzer et al., 2013). Alternatives to peat use are being explored to address concerns regarding reduced long-term sustainability associated with peat harvesting. Potential alternatives include coconut (Cocos nucifera L.) fibers (coir), composts, rice (Oryza sativa L.) hulls, wood chips, biochar, and others (Abad et al., 2002; Alvarez et al., 2017; Buck and Evans, 2010; Barrett et al., 2016; Margenot et al., 2018; Massa et al., 2018; Suo et al., 2013; Xiong et al., 2017). For example, Buck and Evans (2010) and Sambo et al. (2008) found that rice hulls have properties similar to those of peat. Xiong et al. (2017) found that coir, compared to peat, may produce plants of similar size and quality. Furthermore, Abad et al. (2002) found that coir had properties similar to those of peat. Others have found that, based on plant growth or mix properties, biochar from various sources may be suitable as peat alternatives (Alvarez et al., 2017; Margenot et al., 2018; Peterson and Jackson, 2014). Although the effects of such alternatives on plant growth and mix properties vary, the logistics and consistency of products limit their adoption.

One potential organic material that requires further investigation as a peat alternative is processed corn stover (PCS). Corn stover, which is produced at a rate of 185 to $370 \mathrm{Mg}$ annually, is the most abundant and readily available residue in the United States (USDANASS, 2017). A fraction (30\% to 50\%) of the residue produced could be sustainably removed for expanded uses (Blanco-Canqui and Lal, 2009; Graham et al., 2007; Zhao et al., 2015). This means $\approx 92.5$ to $185 \mathrm{Mg}$ can be available for alternative uses. Processed corn stover could have potential as a peat alternative because it may have properties (i.e., $\mathrm{pH}$, nutrient content, and bulk density) similar to those of peat (Pellet Technology USA, Gretna, NE). Research information comparing the use of PCS with peat is, however, limited.

The few previous studies that have evaluated PCS or other crop residues suggested that they may produce biomass yields similar to those of peat (Peterson and Jackson, 2014; Vaughn et al., 2011, 2013). For example, Vaughn et al. (2011) found that using extracted corn tassels at rates of up to $50 \%$ produced tomato yields similar to those of peat but, as tassel rates increased, the bulk density of the mix decreased and the $\mathrm{pH}$ and EC increased. Similarly, Peterson and Jackson (2014) suggested that wheat straw (Triticum aestivum L.) and corn stover biochars produced through gasification could be considered for greenhouse mixes. None of these previous studies assessed ground corn stover or composted stover as alternatives to peat. Therefore, our objectives were to determine how PCS affects the growth and quality of tomatoes and marigolds and to compare the hydraulic and chemical properties of PCS with those of peat.

\section{Materials and Methods}

Experiment design and management

We conducted two greenhouse study experiments (1 and 2) with marigolds ('Bright Yellow Janie') and tomatoes ('Sweet Million Hybrid') during Fall 2017 and early Winter 2017 using the East Campus Greenhouse Facilities at the University of NebraskaLincoln in Lincoln, NE. The experimental design of both studies involved a split-plot, with two plant species (tomatoes and marigolds) as the main plots and stover mixes as the sub-plot. The experimental unit was one plant per pot. Expt. 1 used five stover rates $(0 \%, 25 \%, 50 \%, 75 \%$, and $100 \%$ by volume) mixed with peat as subplots (Table 1). Expt. 2 used 50\% quick stover compost with and without $\mathrm{CaO}, 75 \%$ quick stover compost without $\mathrm{CaO}, 25 \%$ distillers grain amended stover, and $0 \%$ and $25 \%$ stover mixed with 
peat as subplots. Quick compost refers to stover processed through grinding and mechanical shearing. Mechanical shearing refers to fractionation of the fibers of the cell wall, thus making the sugars available. Calcium oxide $(\mathrm{CaO})$ is a chemical means of accelerating the breakdown of the cell wall during shearing and grinding. Distillers grain is a byproduct of the ethanol industry; it is used in the cattle and swine industries as a proteinbased product, the decomposition of which leads to greater $\mathrm{N}$ availability. These additions and additional processing were used to improve the chemical and physical properties of the mix to make it more like peat. The five mix types used for Expt. 1 are hereafter discussed as the "corn stover rates," whereas the six mix types used for Expt. 2 are hereafter discussed as "composted corn stover." Each treatment was replicated 10 times within each experiment.

Greenhouse temperatures averaged $27.7^{\circ} \mathrm{C}$ during the day and $20.6^{\circ} \mathrm{C}$ at night. Plants were illuminated with high-intensity discharge lighting for a 14-h photoperiod throughout both experiments. The corn stover rates experiment was conducted for 6 weeks, and the composted corn experiment was conducted for 5 weeks. Sowing of both species occurred on 11 Aug. 2017 for the stover rates experiment and on 15 Dec. 2017 for the composted stover experiment. Seeds were sown in pre-watered 1206 cell packs containing a 1:1 volume ratio of perlite and vermiculite. Trays were covered with clear plastic domes until $50 \%$ of plants emerged. At that time, domes were propped up $\approx 2.5 \mathrm{~cm}$ to allow airflow while maintaining humidity for the first 3 weeks. Fertilization with $125 \mathrm{mg} \cdot \mathrm{L}^{-1} \mathrm{~N}$ using $20 \mathrm{~N}-4.4 \mathrm{P}-16.6 \mathrm{~K}$ soluble fertilizer (Peter's Professional General Purpose; ICL Fertilizers Worldwide, Dublin, $\mathrm{OH})$ commenced at each watering when plants showed their first true leaves.

All test mixes were mixed by volume and pasteurized using standard greenhouse methods and equipment. Test mixes for both experiments are described in Table 2 . The differences in chemical characteristics between the $25 \%$ stover treatments for Expt. 1 and Expt. 2 were likely due to differences in stover sources. At 4 weeks postseeding, plants with similar sizes and leaf numbers were transplanted to $15-\mathrm{cm}$-diameter plastic pots containing the test mix.

Fertilizer was withheld for the first week after transplanting; then, it was resumed at 125 $\mathrm{mg} \cdot \mathrm{L}^{-1} \mathrm{~N}$ at each watering for the remainder of the experiment ( 6 weeks for stover rates: Expt. 1; 5 weeks for composted stover: Expt. 2). Watering occurred as needed to prevent drought stress, with all plants in each treatment group receiving the same quantity of water. Outflow through the bottom of the pot was measured to determine water use and then discarded. Cumulative water use by each pot was assessed by summing the water applied minus the water outflow throughout the experiment.

\section{Plant growth, relative greenness, and tissue nutrient concentrations}

To determine the influence of the different mix types and ratios (Table 1) on plant

Table 1. Processed corn stover study treatment descriptions and mixing rates for Expt. 1 and Expt. 2.

\begin{tabular}{ll}
\hline Mix Type & \multicolumn{1}{c}{ Mix ratio and components } \\
\hline Stover rate (\%) & \multicolumn{1}{c}{ Corn stover rate experiment $^{2}$} \\
0 & 4 parts peat, 0 parts stover ${ }^{2}$, 4 parts perlite \\
25 & 3 parts peat, 1 part stover, 4 parts perlite \\
50 & 2 parts peat, 2 parts stover, 4 parts perlite \\
75 & 1 part peat, 3 parts stover, 4 parts perlite \\
100 & 0 parts peat, 4 parts stover, 4 parts perlite
\end{tabular}

$0 \%$ Stover

$25 \%$ Stover

$25 \%$ Distillers grain

$50 \%$ Quick compost $+\mathrm{CaO}$

$50 \%$ Quick compost-CaO

75\% Quick compost-CaO

${ }^{\mathrm{z}}$ Stover was ground and passed through 0.94-mm sieves.

Table 2. Initial mix nutrient concentrations for corn stover rate and composted corn stover experiments.

\begin{tabular}{|c|c|c|c|c|c|}
\hline \multirow[b]{2}{*}{ Mix type } & \multirow[b]{2}{*}{$\mathrm{pH}$} & \multirow[b]{2}{*}{$\mathrm{EC}\left(\mathrm{mS} \cdot \mathrm{cm}^{-1}\right)$} & $\mathrm{NO}_{3}$ & $\mathrm{P}$ & $\mathrm{K}$ \\
\hline & & & \multicolumn{3}{|c|}{$\left(\mathrm{mg} \cdot \mathrm{L}^{-1}\right)$} \\
\hline Stover rate $(\%)^{\mathrm{z}}$ & \multicolumn{5}{|c|}{ Corn stover rate experiment } \\
\hline 0 & 5.00 & 0.29 & 0 & 1.6 & 3.4 \\
\hline 25 & 5.22 & 0.53 & 0 & 9.1 & 75.2 \\
\hline 50 & 5.90 & 0.77 & 0 & 21.7 & 183 \\
\hline 75 & 6.68 & 0.88 & 0 & 19.8 & 235 \\
\hline 100 & 7.32 & 1.14 & 0 & 21.9 & 373 \\
\hline & \multicolumn{5}{|c|}{ Composted stover experiment } \\
\hline $0 \%$ Stover & 5.39 & 0.12 & 0.3 & 0 & 2.9 \\
\hline $25 \%$ Stover $^{y}$ & 5.64 & 0.58 & 0.7 & 33 & 145 \\
\hline $25 \%$ Distillers grain ${ }^{x}$ & 5.64 & 1.85 & 1.6 & 112 & 302 \\
\hline $50 \%$ Quick compost $+\mathrm{CaO}^{\mathrm{w}}$ & 6.75 & 3.80 & 0 & 104 & 693 \\
\hline $50 \%$ Quick compost-CaO & 5.69 & 3.18 & 0 & 287 & 759 \\
\hline $75 \%$ Quick compost-CaO & 5.98 & 3.44 & 0 & 292 & 854 \\
\hline
\end{tabular}

${ }^{\mathrm{z}}$ Stover rate is the percentage of $0.94-\mathrm{mm}$ ground stover added by volume to achieve 1:0:1 (peat:stover: perlite), $3: 1: 4,2: 2: 4,1: 3: 4$, and $0: 1: 1$.

${ }^{\mathrm{y}}$ The $0 \%$ and $25 \%$ stover rates were the same composition as in Expt. 1.

${ }^{\mathrm{x}}$ The $25 \%$ distillers grain was composed of 0.94-mm sieved stover plus distillers grain, which was mixed at $3: 1: 4$ (peat:PCS:perlite) to achieve a $25 \%$ rate

${ }^{\text {w}}$ Quick compost stover comprised 0.94-mm sieved stover plus syrup with and without $\mathrm{CaO}$. The quick compost stover with $\mathrm{CaO}$ was mixed at 2:2:4 (peat:PCS:perlite) to achieve a $50 \%$ rate. The quick compost stover without $\mathrm{Ca}$ was mixed at $2: 2: 4$ and $1: 3: 4$ to achieve $50 \%$ and $75 \%$ rates.

growth, we quantified plant height, relative greenness, and the number of flowers or fruit each week after transplanting. We measured plant height from the mix surface to the tip of the uppermost fully expanded leaf. Relative greenness was determined using the SPAD 502 Chlorophyll Meter (Spectrum Technologies, Inc., Aurora, IL) on the uppermost fully expanded leaf.

We measured the biomass yield of aboveground vegetative tissue and reproductive tissue (flowers, fruit, and buds) at the end of the experiment by removing all reproductive tissue and clipping the aboveground vegetative tissue at the mix level. Both aboveground vegetative tissue and reproductive tissue were air-dried in a forcedair oven at $65^{\circ} \mathrm{C}$ for $3 \mathrm{~d}$ and weighed to determine biomass yield. The nitrogen concentration of shoots was assessed using the Dumas method, and $\mathrm{P}, \mathrm{K}, \mathrm{Ca}$, and $\mathrm{Mg}$ concentrations with wetashing digestion were assessed with inductively coupled plasma spectroscopy (Helrich, 1990).

\section{Mix characteristics}

Nutrient concentrations of the mix at the start and at the end of the experiment were determined using saturated extracts (Warncke, 1998; Table 1). Four weeks after transplanting, $5-\times 5-\mathrm{cm}$ metal rings were inserted in the mix to extract intact cores to characterize water retention and available water. Remaining holes were backfilled with the corresponding mix. Extracted cores were leveled at both the top and bottom of the rings, secured with cheesecloth and rubber bands at the bottom of the core to keep the mix inside the cores, and then stored at $4{ }^{\circ} \mathrm{C}$. The cores were slowly saturated from below for $24 \mathrm{~h}$ with deionized water to determine water retention at $-10 \mathrm{kPa}$ matric potential (field capacity) using a pressure plate apparatus (Dane and Hopmans, 2002). After the completion of the analysis at $-10 \mathrm{kPa}$ matric potential, the mixes in the cores were airdried, repacked into $1-\mathrm{cm} \times 5-\mathrm{cm}$ rings, and saturated for $24 \mathrm{~h}$ to determine water retention at $-1500 \mathrm{kPa}$ potential (permanent wilting point). Available water was determined by the difference in volumetric water content between -10 and $-1500 \mathrm{kPa}$ potentials. Bulk density was quantified from the 
intact cores using the core method (Blake and Hartge, 1986).

\section{Statistical analysis}

Data for each experiment and species were analyzed separately. During the corn stover rates experiment, plant height, flower number, relative greenness, and nutrients were correlated with water use. Therefore, the initial statistical analysis consisted of assessing water use as a covariate using the PROC GLIMMIX procedure with repeated measures using SAS 9.4 for a split-plot block design (SAS Institute, 2018). The fixed effects were treatment and week number; the random effect was replication. Because water use did not interact with the stover rate for any variable except for tomato flowers during the final week, we used a model containing only treatment and week number. For nonrepeated measures data (cumulative water use, hydraulic properties, biomass yield, and nutrients) in the corn stover rates experiment, water was also assessed as a covariate, but it had no interaction with the stover rate; therefore, we used a simple model involving only treatment. In the composted corn stover experiment, water use was not correlated with plant height or other variables. Therefore, data were analyzed as repeated measures (PROC GLIMMIX). Before the treatment effects were analyzed, the normal distribution of data was studied using the Shapiro-Wilk test (PROC UNIVARIATE in SAS software). Data transformations were needed only for some nutrient concentrations of plants or mixes. The separation of treatment means was evaluated using Tukey's honestly significant difference at the 0.05 P-level.

\section{Results}

\section{Corn stover rates (Expt. 1)}

Plant growth and relative greenness. The stover rate significantly affected plant height, relative greenness, and flower number for both species. For marigolds, as the stover rate increased, plant height decreased $(r=-0.96 ; P<0.05)$ (Table 3; Fig. 1A). At the end of the experiment, marigold plant heights in the mixes differed as follows: $0 \%>25 \%>50 \%>75 \%=100 \%$ stover. The addition of stover at a rate of $100 \%$ reduced plant height by $5.3 \mathrm{~cm}$ compared with the addition of $25 \%$ stover, and it reduced plant height by $8.7 \mathrm{~cm}$ compared to no stover addition $(0 \%)$.

For tomatoes, plant height decreased with increasing stover rate $(r=-0.99 ; P<0.05)$ (Fig. 1B). At the conclusion of the experiment, the mix with $0 \%$ stover had $70 \%$ taller plants than the mix with $50 \%$ stover, and it had $90 \%$ taller plants than those with $100 \%$ stover. Plant height for mixes with stover rates of $0 \%$ and $25 \%$ did not differ. For both species, the stover rate explained $>80 \%$ of the variability in plant height.

As the stover rate increased, the relative greenness generally decreased (Table 4). For both species, plants growing in mixes with
Table 3. Influence of corn stover rate and composting when mixed with peat and perlite on weekly plant height (mean $\pm \mathrm{SE}$ ) of marigold and tomato in two greenhouse experiments.

\begin{tabular}{|c|c|c|c|c|c|}
\hline \multirow[b]{3}{*}{ Mix type } & \multicolumn{5}{|c|}{ Plant ht $(\mathrm{cm})$} \\
\hline & \multicolumn{5}{|c|}{ Week } \\
\hline & 1 & 2 & 3 & 5 & 6 \\
\hline Stover rate $(\%)^{z}$ & \multicolumn{5}{|c|}{$\begin{array}{l}\text { Corn stover rate experiment } \\
\text { Marigold }\end{array}$} \\
\hline 0 & $11.6 \pm 1.4 \mathrm{a}$ & $12.6 \pm 0.3 \mathrm{a}$ & $15.5 \pm 0.4 \mathrm{a}$ & $17.7 \pm 0.9 \mathrm{a}$ & $17.0 \pm 0.6 \mathrm{a}$ \\
\hline 25 & $10.1 \pm 1.3 \mathrm{a}$ & $8.9 \pm 0.3 b$ & $11.2 \pm 0.3 \mathrm{~b}$ & $13.4 \pm 0.3 b$ & $13.6 \pm 0.4 \mathrm{~b}$ \\
\hline 50 & $9.7 \pm 0.9 \mathrm{~b}$ & $9.1 \pm 0.3 \mathrm{~b}$ & $10.4 \pm 0.2 b$ & $10.6 \pm 0.4 \mathrm{c}$ & $11.0 \pm 0.6 \mathrm{c}$ \\
\hline 75 & $8.9 \pm 0.9 \mathrm{~b}$ & $8.2 \pm 0.3 b c$ & $8.6 \pm 0.2 \mathrm{c}$ & $8.1 \pm 0.3 \mathrm{~d}$ & $7.8 \pm 0.3 \mathrm{~d}$ \\
\hline 100 & $9.4 \pm 0.7 \mathrm{~b}$ & $7.4 \pm 0.4 \mathrm{c}$ & $8.3 \pm 0.4 \mathrm{c}$ & $8.5 \pm 0.7 \mathrm{~cd}$ & $8.3 \pm 0.5 \mathrm{~d}$ \\
\hline $\begin{array}{l}0 \\
25 \\
50 \\
75 \\
100\end{array}$ & $\begin{array}{l}18.1 \pm 1.4 \mathrm{a} \\
13.8 \pm 0.9 \mathrm{~b} \\
13.3 \pm 0.9 \mathrm{~b} \\
13.3 \pm 1.2 \mathrm{~b} \\
13.2 \pm 1.2 \mathrm{~b}\end{array}$ & $\begin{array}{l}35.6 \pm 0.9 \mathrm{a} \\
22.2 \pm 0.5 \mathrm{~b} \\
20.7 \pm 0.8 \mathrm{bc} \\
18.1 \pm 1.0 \mathrm{~cd} \\
16.6 \pm 0.5 \mathrm{~b}\end{array}$ & $\begin{array}{c}\text { Tomato } \\
61.2 \pm 3.0 \mathrm{a} \\
39.4 \pm 2.4 \mathrm{~b} \\
34.3 \pm 1.4 \mathrm{~b} \\
25.1 \pm 1.1 \mathrm{c} \\
21.1 \pm 1.2 \mathrm{c}\end{array}$ & $\begin{array}{l}94.9 \pm 1.8 \mathrm{a} \\
72.1 \pm 1.1 \mathrm{~b} \\
54.9 \pm 3.7 \mathrm{c} \\
31.9 \pm 1.3 \mathrm{~d} \\
29.3 \pm 1.1 \mathrm{~d}\end{array}$ & $\begin{aligned} 112.8 & \pm 2.0 \mathrm{a} \\
99.7 & \pm 3.2 \mathrm{ab} \\
67.1 & \pm 6.9 \mathrm{c} \\
45.4 & \pm 1.0 \mathrm{~d} \\
38.1 & \pm 1.7 \mathrm{~d}\end{aligned}$ \\
\hline \multirow{3}{*}{100} & \multicolumn{5}{|c|}{ Composted stover experiment } \\
\hline & 1 & 2 & 3 & 4 & 5 \\
\hline & \multicolumn{5}{|c|}{ Marigold } \\
\hline $0 \%$ Stover & $9.7 \pm 0.3 \mathrm{a}$ & $12.3 \pm 0.6 \mathrm{a}$ & $14.0 \pm 0.6 \mathrm{a}$ & $15.0 \pm 0.5 \mathrm{a}$ & $15.0 \pm 0.5 \mathrm{a}$ \\
\hline $25 \%$ Stover $^{y}$ & $8.3 \pm 0.6 \mathrm{ab}$ & $10.9 \pm 0.4 \mathrm{ab}$ & $11.2 \pm 0.2 \mathrm{bc}$ & $13.1 \pm 0.5 \mathrm{ab}$ & $13.6 \pm 0.6 \mathrm{ab}$ \\
\hline $25 \%$ Distillers grain ${ }^{x}$ & $8.6 \pm 0.3 \mathrm{ab}$ & $10.5 \pm 0.4 \mathrm{ab}$ & $12.1 \pm 0.5 \mathrm{ab}$ & $14.9 \pm 0.4 \mathrm{a}$ & $15.0 \pm 0.7 \mathrm{a}$ \\
\hline $50 \%$ Quick compost $+\mathrm{CaO}^{\mathrm{w}}$ & $7.6 \pm 0.5 \mathrm{ab}$ & $8.9 \pm 0.3 \mathrm{~b}$ & $9.5 \pm 0.6 \mathrm{c}$ & $11.6 \pm 0.6 \mathrm{~b}$ & $11.3 \pm 0.4 \mathrm{~b}$ \\
\hline $50 \%$ Quick compost-CaO & $8.2 \pm 0.4 \mathrm{ab}$ & $10.0 \pm 0.9 \mathrm{~b}$ & $12.1 \pm 0.6 \mathrm{ab}$ & $13.4 \pm 0.6 \mathrm{ab}$ & $14.5 \pm 0.8 \mathrm{a}$ \\
\hline $75 \%$ Quick compost-CaO & $6.9 \pm 0.5 \mathrm{~b}$ & $8.7 \pm 0.6 \mathrm{~b}$ & $8.9 \pm 0.6 \mathrm{~d}$ & $11.4 \pm 0.6 \mathrm{~b}$ & $12.0 \pm 0.4 \mathrm{~b}$ \\
\hline \multicolumn{6}{|c|}{ Tomato } \\
\hline $0 \%$ Stover & $24.3 \pm 1.3 \mathrm{NS}$ & $46.9 \pm 1.3 \mathrm{a}$ & $58.4 \pm 1.5 \mathrm{a}$ & $85.1 \pm 1.8 \mathrm{a}$ & $100.1 \pm 1.7 \mathrm{a}$ \\
\hline $25 \%$ Stover $^{y}$ & $22.8 \pm 1.0$ & $38.5 \pm 1.6 \mathrm{ab}$ & $50.5 \pm 1.9 \mathrm{bc}$ & $73.4 \pm 1.7 \mathrm{~b}$ & $84.5 \pm 1.9 \mathrm{~b}$ \\
\hline $25 \%$ Distillers grain ${ }^{x}$ & $21.6 \pm 1.6$ & $37.6 \pm 2.8 \mathrm{~b}$ & $51.2 \pm 1.0 \mathrm{~b}$ & $70.4 \pm 3.0 \mathrm{~b}$ & $86.0 \pm 2.9 \mathrm{~b}$ \\
\hline $50 \%$ Quick compost $+\mathrm{CaO}^{\mathrm{w}}$ & $19.9 \pm 1.0$ & $33.4 \pm 1.2 \mathrm{bc}$ & $44.5 \pm 1.6 \mathrm{~cd}$ & $60.8 \pm 1.8 \mathrm{c}$ & $68.9 \pm 2.5 \mathrm{c}$ \\
\hline $50 \%$ Quick compost-CaO & $22.8 \pm 0.8$ & $35.0 \pm 2.9 \mathrm{bc}$ & $47.8 \pm 0.7 \mathrm{bc}$ & $67.2 \pm 2.0 \mathrm{bc}$ & $80.6 \pm 2.5 b$ \\
\hline $75 \%$ Quick compost-CaO & $19.9 \pm 1.7$ & $28.3 \pm 2.3 \mathrm{c}$ & $38.2 \pm 2.5 \mathrm{~d}$ & $50.4 \pm 3.2 \mathrm{~d}$ & $56.7 \pm 2.9 \mathrm{~d}$ \\
\hline
\end{tabular}

Different letters within a week and plant species denote statistical differences among treatments $(P<0.05)$ NS = nonsignificant.

${ }^{\mathrm{z}}$ Stover rate is the percentage of $0.94-\mathrm{mm}$ ground stover added by volume to achieve 1:0:1 (peat:stover: perlite), $3: 1: 4,2: 2: 4,1: 3: 4$, and $0: 1: 1$.

${ }^{\mathrm{y}}$ The $0 \%$ and $25 \%$ stover rates were the same composition as in Expt. 1.

${ }^{\mathrm{x}}$ The $25 \%$ distillers grain was composed of $0.94-\mathrm{mm}$ sieved stover plus distillers grain, which was mixed at 3:1:4 (peat:PCS:perlite) to achieve a $25 \%$ rate.

${ }^{\text {w}}$ Quick compost stover comprised 0.94-mm sieved stover plus syrup with and without $\mathrm{CaO}$. The quick compost stover with $\mathrm{CaO}$ was mixed at 2:2:4 (peat:PCS:perlite) to achieve a 50\% rate. The quick compost stover without $\mathrm{Ca}$ was mixed at $2: 2: 4$ and $1: 3: 4$ to achieve $50 \%$ and $75 \%$ rates.
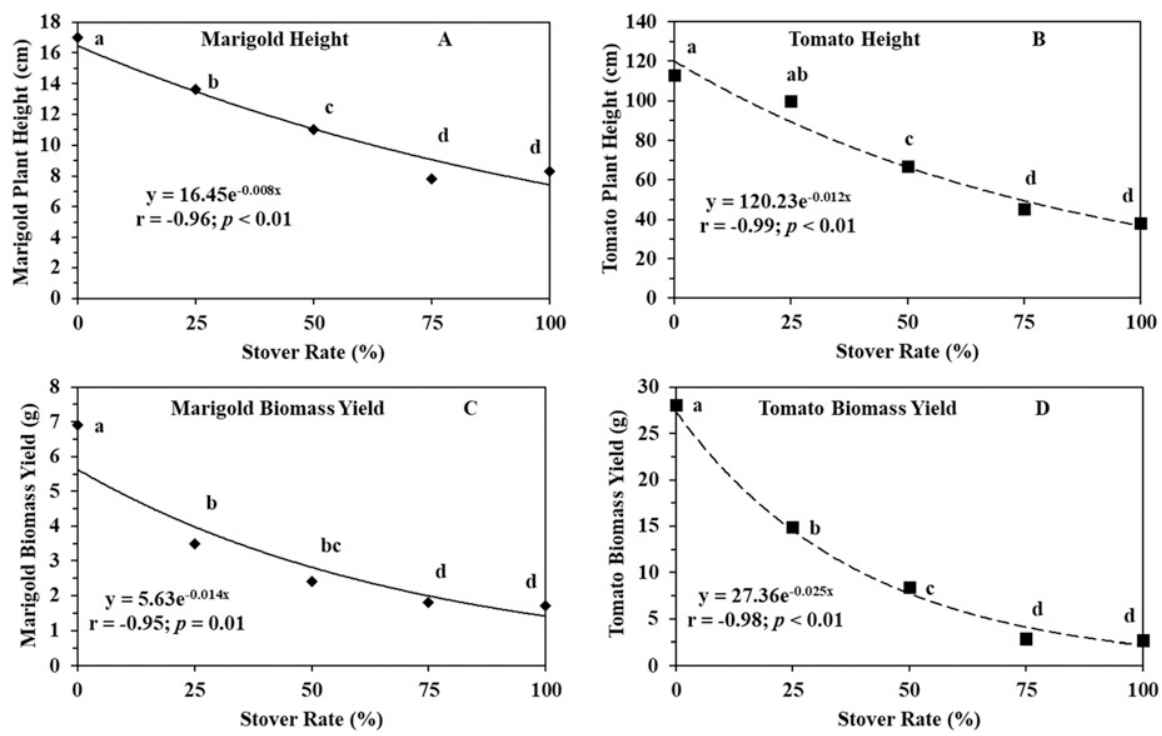

Fig. 1. Influence of corn stover rate when mixed with peat and perlite on the heights of marigold (A) and tomato $(\mathbf{B})$ and on the aboveground biomass yield of marigold $(\mathbf{C})$ and tomato $(\mathbf{D})$. Different letters within a plant species denote statistical differences among treatments. Stover rate is the percentage of 0.94-mm ground stover added by volume to achieve 1:0:1 (peat:stover:perlite), 3:1:4, $2: 2: 4,1: 3: 4$, and $0: 1: 1$ 
$0 \%, 25 \%$, and $50 \%$ stover had similar relative greenness, but they were greener than plants growing in mixes with $100 \%$ stover. For marigolds, the mix without stover had 17 flowers, but those with $100 \%$ stover had only 4 flowers (Table 5). Adding stover at $25 \%$ resulted in $31 \%$ fewer flowers compared to $0 \%$ stover; however, adding $25 \%$ stover resulted in more flowers than treatments with $>25 \%$ stover. For tomatoes, the mix without stover had 41 flowers, whereas mixes with $25 \%$ stover had 15 flowers and mixes with $>50 \%$ stover had fewer than 3 flowers. Water application interacted with flower number, but only during week 6 , when the number of flowers decreased with the decreasing cumulative water applied across all treatments $(r=$ $-0.93 ; P<0.001)$. The stover rate affected the aboveground vegetative and reproductive biomass yields of both species (Fig. 1C and D). For both species, as the stover amount increased, the vegetative biomass yield decreased. The addition of stover generally affected aboveground biomass yield in the following order: $0 \%>25 \%>50 \%>75 \%=$ $100 \%$ stover.

Plant tissue and mix nutrient concentrations. Stover rate affected plant tissue and mix nutrient concentrations for both species (Tables 6 and 7). For marigold vegetative tissue, as the stover rate increased, tissue $\mathrm{N}$ concentration decreased in the following order: $0 \%=25 \%>50 \%>75 \%>100 \%$ stover. The addition of stover at rates $\leq 50 \%$ reduced tissue $\mathrm{P}$ concentrations relative to the addition of $75 \%$ or $100 \%$ stover. In the case of $\mathrm{Ca}$, mixes without stover had the highest concentration. However, the mix with $100 \%$ stover had generally higher $\mathrm{K}$ and $\mathrm{Mg}$ concentrations compared with most other stover rates. For tomatoes, the effects of stover addition on $\mathrm{N}$ concentrations were similar to those of marigolds. The effects occurred in the following order: $0 \%=25 \%=50 \%$ (highest concentration) $>75 \%>100 \%$ stover. The stover amount in the mix affected $\mathrm{P}$ concentration in the following order: $0 \%=$ $25 \%>50 \%=75 \%>100 \%$ stover. The mix with the $100 \%$ stover rate had higher $\mathrm{Mg}$ concentration than mixes with $0 \%, 25 \%$, and $50 \%$ stover. Stover addition did not affect the $\mathrm{Ca}$ concentration; however, $\mathrm{K}$ concentration increased with the increasing rates of stover additions.

For both species, stover rate affected the chemical composition of the mix (Table 7). As stover rate increased, $\mathrm{pH}$ and $\mathrm{K}$ concentration of the mix increased, whereas $\mathrm{NO}_{3}{ }^{-}$concentration generally decreased. Stover rate had mixed effects on EC. For marigolds, P concentration in the mix with $0 \%$ stover was the highest; however, the concentration in the mix with $75 \%$ stover was similar to mixes with $0 \%$ stover and all other stover rates. For tomato, the order of $\mathrm{P}$ concentration in the mix was as follows: $25 \%$ stover $>0 \%$ stover $>$ all other rates.

Select physical properties of the mix. The addition of stover significantly impacted cumulative water use (Fig. 3), bulk density, porosity, and water retention (Table 8). As

Table 4. Influence of corn stover rate and composting when mixed with peat and perlite on weekly relative greenness from uppermost fully expanded leaf (SPAD readings) (mean $\pm \mathrm{SE}$ ) of marigold and tomato in two greenhouse experiments.

\begin{tabular}{lccccc}
\hline & \multicolumn{5}{c}{ Relative greenness (SPAD units) } \\
\cline { 2 - 6 } Mix type & \multicolumn{5}{c}{ Week } \\
\cline { 2 - 6 } Stover rate $(\%)^{\mathrm{z}}$ & \multicolumn{5}{c}{ Corn stover rate experiment } \\
& & \multicolumn{4}{c}{ Marigold } \\
0 & $45 \pm 1 \mathrm{a}$ & $49 \pm 1 \mathrm{a}$ & $52 \pm 2 \mathrm{a}$ & $59 \pm 1 \mathrm{a}$ & $62 \pm 2 \mathrm{a}$ \\
25 & $41 \pm 1 \mathrm{ab}$ & $44 \pm 2 \mathrm{ab}$ & $46 \pm 3 \mathrm{ab}$ & $53 \pm 2 \mathrm{ab}$ & $54 \pm 3 \mathrm{a}$ \\
50 & $41 \pm 1 \mathrm{bc}$ & $38 \pm 3 \mathrm{bc}$ & $40 \pm 4 \mathrm{bc}$ & $45 \pm 2 \mathrm{bc}$ & $53 \pm 1 \mathrm{a}$ \\
75 & $41 \pm 2 \mathrm{~cd}$ & $35 \pm 3 \mathrm{c}$ & $32 \pm 3 \mathrm{c}$ & $36 \pm 3 \mathrm{~cd}$ & $44 \pm 3 \mathrm{~b}$ \\
100 & $40 \pm 2 \mathrm{~d}$ & $27 \pm 2 \mathrm{c}$ & $32 \pm 2 \mathrm{c}$ & $31 \pm 2 \mathrm{~d}$ & $31 \pm 3 \mathrm{c}$ \\
& & & & & \\
0 & $43 \pm 2 \mathrm{NS}$ & $54.1 \pm 2 \mathrm{a}$ & $55 \pm 2 \mathrm{a}$ & $54 \pm 1 \mathrm{a}$ & $62 \pm 4 \mathrm{a}$ \\
25 & $42 \pm 2$ & $43.8 \pm 3 \mathrm{~b}$ & $46 \pm 1 \mathrm{~b}$ & $56 \pm 1 \mathrm{a}$ & $60 \pm 2 \mathrm{a}$ \\
50 & $38 \pm 2$ & $44.4 \pm 2 \mathrm{~b}$ & $44 \pm 3 \mathrm{~b}$ & $49 \pm 1 \mathrm{~b}$ & $55 \pm 2 \mathrm{ab}$ \\
75 & $43 \pm 1$ & $39.5 \pm 1 \mathrm{bc}$ & $41 \pm 3 \mathrm{bc}$ & $41 \pm 2 \mathrm{c}$ & $51 \pm 2 \mathrm{~b}$ \\
100 & $41 \pm 1$ & $35.7 \pm 2 \mathrm{c}$ & $36 \pm 2 \mathrm{c}$ & $37 \pm 2 \mathrm{~d}$ & $43 \pm 2 \mathrm{c}$
\end{tabular}

$0 \%$ Stover

$25 \%$ Stover $^{\mathrm{y}}$

$25 \%$ Distillers grain ${ }^{\mathrm{x}}$

$50 \%$ Quick compost $+\mathrm{CaO}^{\mathrm{w}}$

$50 \%$ Quick compost-CaO

75\% Quick compost-CaO

$0 \%$ Stover

$25 \%$ Stover $^{\mathrm{y}}$

$25 \%$ Distillers grain ${ }^{\mathrm{x}}$

$50 \%$ Quick compost $+\mathrm{CaO}^{\mathrm{w}}$

$50 \%$ Quick compost-CaO

75\% Quick compost-CaO

Composted stover experiment

\begin{tabular}{ccccc}
\hline \multicolumn{1}{c}{2} & \multicolumn{1}{c}{3} & 4 & 5 \\
\hline $42 \pm 1 \mathrm{NS}$ & $56 \pm 1 \mathrm{NS}$ & $57 \pm 3 \mathrm{a}$ & $57 \pm 2 \mathrm{a}$ & $56 \pm 2 \mathrm{ab}$ \\
$39 \pm 2$ & $57 \pm 5$ & $49 \pm 2 \mathrm{ab}$ & $53 \pm 2 \mathrm{ab}$ & $51 \pm 2 \mathrm{ab}$ \\
$43 \pm 1$ & $55 \pm 2$ & $54 \pm 3 \mathrm{a}$ & $59 \pm 3 \mathrm{a}$ & $59 \pm 1 \mathrm{a}$ \\
$34 \pm 4$ & $44 \pm 4$ & $42 \pm 3 \mathrm{~b}$ & $41 \pm 3 \mathrm{~b}$ & $48 \pm 3 \mathrm{~b}$ \\
$41 \pm 1$ & $52 \pm 2$ & $51 \pm 3 \mathrm{ab}$ & $51 \pm 4 \mathrm{ab}$ & $56 \pm 2 \mathrm{ab}$ \\
$37 \pm 2$ & $43 \pm 5$ & $50 \pm 3 \mathrm{ab}$ & $45 \pm 5 \mathrm{ab}$ & $48 \pm 3 \mathrm{~b}$
\end{tabular}

Different letters within a week and plant species denote statistical differences among treatments $(P<0.05)$ NS = nonsignificant.

${ }^{\mathrm{z}}$ Stover rate is the percentage of $0.94-\mathrm{mm}$ ground stover added by volume to achieve 1:0:1 (peat:stover: perlite), $3: 1: 4,2: 2: 4,1: 3: 4$, and $0: 1: 1$.

${ }^{\mathrm{y}}$ The $0 \%$ and $25 \%$ stover rates were the same composition as in Expt. 1.

${ }^{\mathrm{x}}$ The $25 \%$ distillers grain was composed of $0.94-\mathrm{mm}$ sieved stover plus distillers grain, which was mixed at 3:1:4 (peat:PCS:perlite) to achieve a $25 \%$ rate.

${ }^{\text {w}}$ Quick compost stover comprised 0.94-mm sieved stover plus syrup with and without $\mathrm{CaO}$. The quick compost stover with $\mathrm{CaO}$ was mixed at 2:2:4 (peat:PCS:perlite) to achieve a $50 \%$ rate. The quick compost stover without $\mathrm{Ca}$ was mixed at $2: 2: 4$ and $1: 3: 4$ to achieve $50 \%$ and $75 \%$ rates.

the stover rate in the mix increased, cumulative water use decreased (Fig. 2). The decrease in the cumulative water use from $0 \%$ to $100 \%$ stover was 3.3 -times for marigolds and 5.1-times for tomatoes. Mixes with stover rates of $50 \%, 75 \%$, and $100 \%$ had lower bulk density and greater porosity than those with $0 \%$ stover. The addition of stover did not affect volumetric water content at saturation or permanent wilting point. However, mixes with $0 \%$ and $25 \%$ stover had $35 \%$ greater available water than the mix with $100 \%$ stover. As the stover rate increased, water content at field capacity decreased $(r=-0.97 ; P<0.05)$ and available water content decreased $(r=-0.94 ; P<$ $0.05)$; however, there was no correlation with permanent wilting point $(r=0.13 ; P>$ $0.05)$.

\section{Composted stover (Expt. 2)}

Plant growth and relative greenness. The composted stover type affected plant height and flower numbers. The effects on greenness differed between tomatoes and marigolds.
For marigolds, mixes with $50 \%$ quick compost $+\mathrm{CaO}$ and $75 \%$ quick compost- $\mathrm{CaO}$ had shorter plants than those with $0 \%$ stover, $25 \%$ distillers grain, and $50 \%$ quick compost- $\mathrm{CaO}$, which had similar plant heights (Table 3). For tomatoes, composted stover type affected height in the following order: $0 \%$ stover $>25 \%$ distillers grain $=25 \%$ stover $=50 \%$ quick compost- $\mathrm{CaO}>50 \%$ quick compost $+\mathrm{CaO}$ $>75 \%$ quick compost- $\mathrm{CaO}$.

For marigolds, mixes with $50 \%$ quick compost- $\mathrm{CaO}, 25 \%$ distillers grain, and $0 \%$ stover had plants with similar relative greenness; however, those with $25 \%$ distillers grain had plants with $23 \%$ greater greenness than mixes with $50 \%$ quick compost $+\mathrm{CaO}$ and $75 \%$ quick compost- $\mathrm{CaO}$ (Table 4). For tomatoes, mix type did not affect relative greenness during week 4 or week 5 . Marigold plants grown in mixes with the addition of $0 \%$ and $25 \%$ stover had nearly double the flower number of the $75 \%$ quick compost-CaO (Table 5). Tomato plants grown in the mix with $25 \%$ distillers grain had more flowers than those grown in $50 \%$ 
quick compost $+\mathrm{CaO}$ and $75 \%$ quick compost-CaO.

The composted stover type also affected aboveground vegetative biomass yield, but the effects on reproductive biomass yield differed between tomatoes and marigolds (Fig. 3A and B). For marigolds, treatments of $0 \%$ stover, $25 \%$ distillers grain, and $50 \%$ quick compost$\mathrm{CaO}$ had $53 \%$ greater vegetative biomass yield than $25 \%$ stover, $75 \%$ quick compost$\mathrm{CaO}$, and $50 \%$ quick compost $+\mathrm{CaO}$ (Fig. $3 \mathrm{~A}$ ). For tomatoes, the mix with $25 \%$ distillers grain had $36 \%$ greater vegetative biomass yield than $0 \%$ stover and $50 \%$ quick compost-CaO, the next highest biomass yielding treatments. All other treatments had similar aboveground biomass yields $<8 \mathrm{~g}$. For marigolds, treatments of $0 \%$ stover, $25 \%$ stover, $25 \%$ distillers grain, and $50 \%$ quick compost-CaO had similar reproductive biomass yields; however, the mix without stover had nearly double the biomass yield of the mix with $75 \%$ quick compost-CaO (Fig. 3B). Treatments did not affect tomato reproductive biomass yield.

Plant tissue and mix nutrient concentrations. Mix type affected plant tissue and mix nutrient concentrations (Tables 6 and 7). For marigolds, composted stover treatments affected $\mathrm{N}$ concentration in the following order: $25 \%$ distillers grain (highest $\mathrm{N}$ ) $>75 \%$ quick compost- $\mathrm{CaO}=$ $50 \%$ quick compost-CaO; however, $50 \%$ quick compost- $\mathrm{CaO}=0 \%$ stover $>50 \%$ quick compost $+\mathrm{CaO}=25 \%$ stover. A similar pattern was true for $\mathrm{P}$, except the mixes with $25 \%$ distillers grain had a significantly greater $P$ concentration in marigold leaves. All three quick compost treatments had the highest $\mathrm{K}$ tissue concentrations. The mixes with $0 \%$ stover and $50 \%$ quick compost $+\mathrm{CaO}$ produced the highest $\mathrm{Mg}$ tissue concentration. The mix without stover had the highest tissue $\mathrm{Ca}$ concentration; then, the following order was observed: $25 \%$ stover $=50 \%$ quick compost $+\mathrm{CaO}>25 \%$ distillers grain $>$ $75 \%$ quick compost- $\mathrm{CaO}=50 \%$ quick compost-CaO. Tomatoes had similar patterns of $\mathrm{N}, \mathrm{P}$, and $\mathrm{K}$ tissue concentrations, and tissue $\mathrm{Ca}$ concentrations were affected by mix type in the following order: $50 \%$ quick compost $+\mathrm{CaO}=$ $25 \%$ stover and $25 \%$ stover $=0 \%$ stover $>25 \%$ distillers grain $=50 \%$ quick compost-CaO > $75 \%$ quick compost-CaO.

The mix without stover had the lowest $\mathrm{pH}$ of all treatments, and the $\mathrm{pH}$ was greatest in the three quick compost treatments. The EC was generally similar for both species as follows: $75 \%$ quick compost-CaO $>50 \%$ quick compost- $\mathrm{CaO}=50 \%$ quick compost $+\mathrm{CaO} \leq 25 \%$ distillers grain. Phosphorus and $\mathrm{K}$ concentrations generally followed a pattern similar to that of EC. Nitrate concentrations differed between marigolds and tomatoes. For marigolds, all composted stover treatments had higher $\mathrm{NO}_{3}{ }^{-}$concentrations than $25 \%$ stover rate; however, for tomatoes, $\mathrm{NO}_{3}^{-}$concentrations were unaffected by the mix type.

Select physical properties of mixes. Composted stover type affected cumulative water use, bulk density, porosity, and water retention parameters. For marigolds, water use was $25 \%$ greater for the mix without

Table 5. Influence of corn stover rate and composting when mixed with peat and perlite on weekly flower plus fruit number (mean $\pm \mathrm{SE}$ ) of marigold and tomato in two greenhouse experiments.

\begin{tabular}{|c|c|c|c|c|c|}
\hline \multirow[b]{3}{*}{ Mix type } & \multicolumn{5}{|c|}{ Flower and fruit number } \\
\hline & \multicolumn{5}{|c|}{ Week } \\
\hline & 1 & 2 & 3 & 5 & 6 \\
\hline Stover rate $(\%)^{\mathrm{z}}$ & \multicolumn{5}{|c|}{$\begin{array}{c}\text { Corn stover rate experiment } \\
\text { Marigold }\end{array}$} \\
\hline 0 & \multirow[t]{5}{*}{ None } & $0.7 \pm 0.2 \mathrm{NS}$ & $4.8 \pm 0.6 \mathrm{a}$ & $9.0 \pm 0.9 \mathrm{a}$ & $17.4 \pm 1.5 \mathrm{a}$ \\
\hline 25 & & $1.1 \pm 0.3$ & $3.5 \pm 0.5 \mathrm{ab}$ & $7.0 \pm 0.8 \mathrm{ab}$ & $13.3 \pm 1.3 \mathrm{~b}$ \\
\hline 50 & & $1.3 \pm 0.2$ & $3.4 \pm 0.2 \mathrm{ab}$ & $5.4 \pm 0.7 \mathrm{bc}$ & $10.5 \pm 0.7 b$ \\
\hline 75 & & $0.6 \pm 0.2$ & $2.6 \pm 0.2 \mathrm{~b}$ & $4.3 \pm 0.5 \mathrm{bc}$ & $5.8 \pm 0.7 \mathrm{c}$ \\
\hline \multirow[t]{2}{*}{100} & & $0.6 \pm 0.2$ & $2.1 \pm 0.3 \mathrm{~b}$ & $3.2 \pm 0.6 \mathrm{c}$ & $4.0 \pm 0.5 \mathrm{c}$ \\
\hline & \multicolumn{5}{|c|}{ Tomato } \\
\hline 0 & None & None & $4.6 \pm 0.7 \mathrm{a}$ & $12.0 \pm 2.6 \mathrm{a}$ & $40.7 \pm 4 \mathrm{a}$ \\
\hline 25 & & & $0.4 \pm 0.1 \mathrm{~b}$ & $4.3 \pm 0.8 b$ & $15.4 \pm 0.9 b$ \\
\hline 50 & & & $0.2 \pm 0.3 b$ & $2.0 \pm 0.9 \mathrm{~b}$ & $8.3 \pm 1.3 \mathrm{c}$ \\
\hline 75 & & & $0 \pm 0 \mathrm{~b}$ & $0.7 \pm 0.5 \mathrm{c}$ & $2.6 \pm 0.5 \mathrm{c}$ \\
\hline \multirow[t]{4}{*}{100} & & & $0 \pm 0 \mathrm{~b}$ & $0.3 \pm 0.3 \mathrm{c}$ & $2.1 \pm 0.5 \mathrm{c}$ \\
\hline & \multicolumn{5}{|c|}{ Composted stover experiment } \\
\hline & 1 & 2 & 3 & 4 & 5 \\
\hline & \multicolumn{5}{|c|}{ Marigold } \\
\hline $0 \%$ Stover & None & None & $1.5 \pm 0.5 \mathrm{a}$ & $4.9 \pm 0.8 \mathrm{a}$ & $6.0 \pm 1.0 \mathrm{a}$ \\
\hline $25 \%$ Stover $^{\mathrm{y}}$ & & & $0.9 \pm 0.4 \mathrm{ab}$ & $2.5 \pm 0.6 \mathrm{~b}$ & $6.1 \pm 0.7 \mathrm{a}$ \\
\hline $25 \%$ Distillers grain ${ }^{x}$ & & & $0.6 \pm 0.2 \mathrm{ab}$ & $2.5 \pm 0.5 b$ & $5.1 \pm 0.8 \mathrm{ab}$ \\
\hline $50 \%$ Quick compost $+\mathrm{CaO}^{\mathrm{w}}$ & & & $0.5 \pm 0.2 \mathrm{~b}$ & $2.2 \pm 0.5 \mathrm{~b}$ & $4.5 \pm 0.7 \mathrm{ab}$ \\
\hline $50 \%$ Quick compost-CaO & & & $0.5 \pm 0.2 \mathrm{~b}$ & $2.6 \pm 0.4 b$ & $4.7 \pm 0.5 \mathrm{ab}$ \\
\hline \multirow[t]{2}{*}{$75 \%$ Quick compost-CaO } & & & $0.3 \pm 0.2 \mathrm{~b}$ & $1.8 \pm 0.3 \mathrm{~b}$ & $3.3 \pm 0.5 \mathrm{~b}$ \\
\hline & \multicolumn{5}{|c|}{ Tomato } \\
\hline $0 \%$ Stover & None & None & $1.2 \pm 0.5 \mathrm{NS}$ & $6.7 \pm 1.3 \mathrm{NS}$ & $14.5 \pm 2.3 \mathrm{ab}$ \\
\hline $25 \%$ Stover $^{\mathrm{y}}$ & & & $0.6 \pm 0.6$ & $2.9 \pm 1.0$ & $10.7 \pm 2.3 \mathrm{~b}$ \\
\hline $25 \%$ Distillers grain ${ }^{x}$ & & & $0.8 \pm 0.7$ & $6.4 \pm 1.3$ & $20.1 \pm 2.9 \mathrm{a}$ \\
\hline $50 \%$ Quick compost $+\mathrm{CaO}^{\mathrm{w}}$ & & & $0 \pm 0$ & $4.7 \pm 1.2$ & $10.7 \pm 1.7 \mathrm{~b}$ \\
\hline $50 \%$ Quick compost-CaO & & & $0.4 \pm 0.4$ & $4.1 \pm 1.3$ & $12.5 \pm 2.0 \mathrm{ab}$ \\
\hline 75\% Quick compost-CaO & & & $0 \pm 0$ & $3.1 \pm 1.0$ & $8.3 \pm 1.9 \mathrm{~b}$ \\
\hline
\end{tabular}

Different letters within a week and plant species denote statistical differences among treatments $(P<0.05)$. NS = nonsignificant.

${ }^{\mathrm{z}}$ Stover rate is the percentage of $0.94-\mathrm{mm}$ ground stover added by volume to achieve 1:0:1 (peat:stover: perlite), $3: 1: 4,2: 2: 4,1: 3: 4$, and $0: 1: 1$.

${ }^{\mathrm{y}}$ The $0 \%$ and $25 \%$ stover rates were the same composition as in Expt. 1.

${ }^{\mathrm{x}}$ The $25 \%$ distillers grain was composed of $0.94-\mathrm{mm}$ sieved stover plus distillers grain, which was mixed at $3: 1: 4$ (peat:PCS:perlite) to achieve a $25 \%$ rate.

${ }^{\mathrm{w}}$ Quick compost stover comprised 0.94-mm sieved stover plus syrup with and without $\mathrm{CaO}$. The quick compost stover with $\mathrm{CaO}$ was mixed at 2:2:4 (peat:PCS:perlite) to achieve a $50 \%$ rate. The quick compost stover without $\mathrm{Ca}$ was mixed at 2:2:4 and 1:3:4 to achieve $50 \%$ and $75 \%$ rates.

stover than for the $50 \%$ quick compost and $25 \%$ stover treatments (Fig. 2). For tomatoes, water use was greatest for mixes without stover, with $25 \%$ distillers grain, and with $50 \%$ quick compost-CaO compared with most other treatments. There were small but significant differences in bulk density and porosity, with the $0 \%$ stover treatment having bulk density and porosity comparable to $25 \%$ distillers grain and $25 \%$ stover treatments (Table 8). The $50 \%$ quick compost $+\mathrm{CaO}$ treatment had lower volumetric water content at saturation compared with most treatments. Volumetric water content at field capacity, permanent wilting point, and available water were unaffected by treatments.

\section{Discussion}

\section{Corn stover as an alternative to peat}

Our results suggest that plant growth can decrease exponentially as the amount of ground stover added to the mix increased (Table 3; Fig. 1A). The decrease in plant growth was particularly large with high rates $(\geq 50 \%)$ of stover additions (Fig. 1A). The latter suggests that although large additions of stover may not adequately support plant growth compared with the $0 \%$ stover ( 1 peat: 1 perlite), low stover addition rates showed some promise. For example, the mix with $25 \%$ stover (3 peat: 1 stover: 4 perlite) had plant growth similar to that of the mix without stover (Table 3), suggesting that the addition of stover at levels $<50 \%$ may be a potential alternative to peat. The reduction in marigold height between $75 \%$ and $100 \%$ stover (Table 3) was potentially due to shrinkage of the mix because plants were measured from the top of the mix to the tip of the topmost fully expanded leaf. Poor plant growth in mixes with high stover rates was likely due to the lack of water or nutrient retention. For instance, the lower bulk density and higher porosity with stover inclusion rates $\geq 50 \%$ led to lower plant-available water, particularly between $0 \%$ and $100 \%$ stover (Table 8 ).

The similarity in relative greenness among $0 \%, 25 \%$, and $50 \%$ stover addition treatments suggests that plants grown with these levels of stover were of higher quality compared with those grown with $100 \%$ stover (Table 4). 
Table 6. Influence of corn stover rate and composting when mixed with peat and perlite on nutrient concentration (mean $\pm \mathrm{SE}$ ) of marigold and tomato plant tissue in two greenhouse experiments.

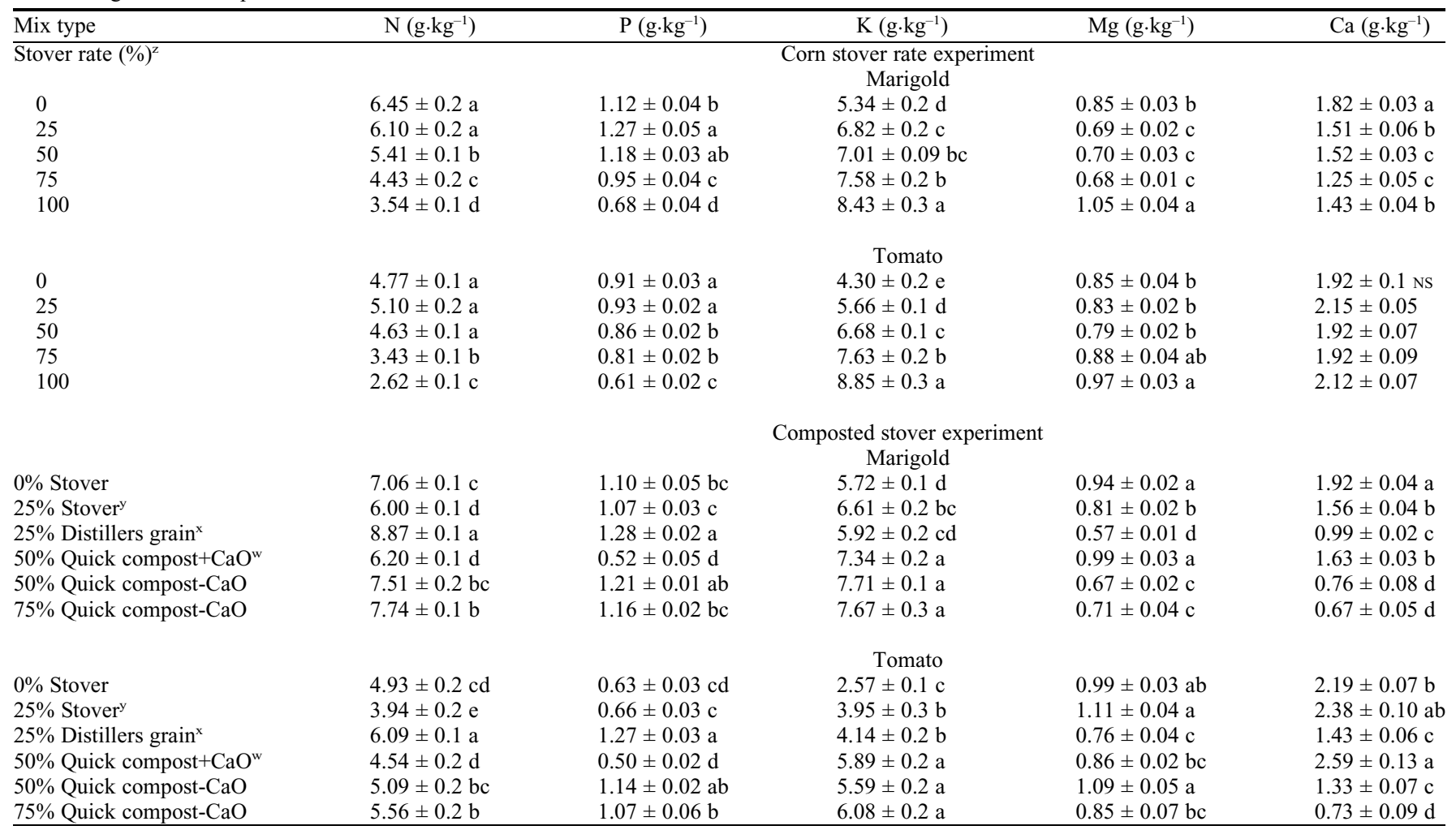

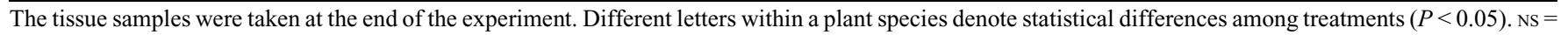
nonsignificant.

${ }^{\mathrm{z}}$ Stover rate is the percentage of $0.94-\mathrm{mm}$ ground stover added by volume to achieve 1:0:1 (peat:stover:perlite), 3:1:4, 2:2:4, 1:3:4, and 0:1:1.

${ }^{\mathrm{y}}$ The $0 \%$ and $25 \%$ stover rates were the same composition as in Expt. 1.

${ }^{\mathrm{x}}$ The 25\% distillers grain was composed of 0.94-mm sieved stover plus distillers grain, which was mixed at 3:1:4 (peat:PCS:perlite) to achieve a 25\% rate.

${ }^{\text {w }}$ Quick compost stover comprised $0.94-\mathrm{mm}$ sieved stover plus syrup with and without CaO. The quick compost stover with CaO was mixed at 2:2:4 (peat:PCS: perlite) to achieve a 50\% rate. The quick compost stover without Ca was mixed at 2:2:4 and 1:3:4 to achieve 50\% and 75\% rates.

This was supported by the higher tissue $\mathrm{N}$ and $\mathrm{P}$ concentrations with the lower stover rates, which potentially indicated less nutrient immobilization in these mixes (Table 6). The higher $\mathrm{pH}$ associated with stover rates of $75 \%$ and $100 \%$ compared with lower stover rates may have resulted in the unavailability of some nutrients (Table 7). The immobilization of nutrients was supported by the lower $\mathrm{NO}_{3}{ }^{-}$ concentrations in the $75 \%$ and $100 \%$ stover mixes (Tables 6-8). However, the generally similar chemical and physical properties of the mix with $25 \%$ stover compared to those with $0 \%$ stover suggested that the mix with $25 \%$ stover may be used in the greenhouse industry after further assessment.

Previous studies that evaluated the use of different rates of peat alternatives showed generally positive effects of peat alternatives on plant growth when used at relatively low rates $(\leq 50 \%)$ (Shanan et al., 2016; Vaughn et al., 2011). For example, a study using extracted and ground corn tassels found that tomato height and fruit numbers were unaffected by tassel rates $<50 \%$ (Vaughn et al., 2011). In a study using peanut (Arachis hypogaea L.) shells, shoot length of petunia (Petunia sp.) was greater with $30 \%, 50 \%$, and $70 \%$ peanut shell rates compared with peat, but biomass yield was greatest with the $50 \%$ peanut shell rate (Shanan et al., 2016).
Results of the effects of the stover rates on physical and chemical properties of the mix were generally similar to those of previous studies when peat alternatives were included at rates $\geq 50 \%$ (Shanan et al., 2016; Vaughn et al., 2011). Using peanut shells at rates of $30 \%, 50 \%$, or $70 \%$ reduced water retention compared to peat (Shanan et al., 2016). Similarly, the use of extracted sweet corn tassels decreased bulk density and increased $\mathrm{pH}$ and $\mathrm{EC}$ at $50 \%$ inclusion, thus reducing fruit numbers compared to rates $<50 \%$ (Vaughn et al., 2011).

\section{Composted corn stover as an alternative to peat}

The relatively similar plant growth and biomass yields of mixes with $0 \%$ stover and with $25 \%$ distillers grain for both species (Table 3; Fig. 1B) suggests that the addition of $25 \%$ distillers grain (3 peat: 1 distillers grain: 4 perlite) adequately supported plant growth compared to most other treatments. It should be noted that other treatments had plant growth similar to that of $0 \%$ stover and $25 \%$ distillers grain, but performance differed by species; therefore, we focused on the mix with the best characteristics and plant performance across both species.

The poor plant growth with $50 \%$ quick compost $+\mathrm{CaO}$ and $75 \%$ quick compost- $\mathrm{CaO}$ was potentially due to the chemical and physical properties of the mix. Overall, the physical properties of the mix suggested that the mixes were generally similar in their water availability, although bulk density was generally lower with $0 \%$ and $25 \%$ stover and $25 \%$ distillers grain, thus leading to greater porosity (Table 8). However, the chemistry of the mixes was problematic (Table 7). The $\mathrm{pH}$ was $\approx 7.0$ for most mixes, which is considered marginal for greenhouse mixes (ideal $\mathrm{pH}$ range, 5.5-6.5). However, EC was significantly greater with any processed stover except for $25 \%$ stover and $25 \%$ distillers grain, which had almost identical EC responses to $0 \%$ stover.

The similarity in relative greenness between $0 \%$ stover and $25 \%$ distillers grain indicates that plants growing in these mixes are of better quality or healthier than those growing in other mixes (Table 4). This was supported by the greater $\mathrm{N}$ and $\mathrm{P}$ concentrations with $0 \%$ stover and $25 \%$ distillers grain compared with low performing treatments $(50 \%$ quick compost $+\mathrm{CaO}$ and $75 \%$ quick compost- $\mathrm{CaO}$ ) (Table 6). The mixes with the greatest $\mathrm{pH}$ or EC values, particularly with $\mathrm{pH}>7$ and $\mathrm{EC}>2.2 \mathrm{mS} \cdot \mathrm{cm}^{-1}$ $(50 \%$ quick compost $+\mathrm{CaO}, 75 \%$ quick compost-CaO), also had plants with the lowest biomass production, suggesting that 
Table 7. Influence of corn stover rate and composting when mixed with peat and perlite on nutrient concentration (mean $\pm \mathrm{SE}$ ) of the mix for marigolds and tomatoes in two greenhouse experiments.

\begin{tabular}{|c|c|c|c|c|c|}
\hline Mix type & $\mathrm{pH}$ & $\mathrm{EC}\left(\mathrm{mS} \cdot \mathrm{cm}^{-1}\right)$ & $\mathrm{NO}_{3-}\left(\mathrm{mg} \cdot \mathrm{L}^{-1}\right)$ & $\mathrm{P}\left(\mathrm{mg} \cdot \mathrm{L}^{-1}\right)$ & $\mathrm{K}\left(\mathrm{mg} \cdot \mathrm{L}^{-1}\right)$ \\
\hline Stover rate $(\%)^{\mathrm{z}}$ & \multicolumn{5}{|c|}{$\begin{array}{c}\text { Corn stover rate experiment } \\
\text { Marigold }\end{array}$} \\
\hline 0 & $5.5 \pm 0.07 \mathrm{c}$ & $1.5 \pm 0.10 \mathrm{ab}$ & $132.3 \pm 12.3 \mathrm{a}$ & $33.8 \pm 1.7 \mathrm{a}$ & $101.6 \pm 5.3 \mathrm{~d}$ \\
\hline 25 & $6.3 \pm 0.15 b$ & $1.0 \pm 0.07 \mathrm{c}$ & $64.9 \pm 11.0 \mathrm{~b}$ & $25.3 \pm 1.2 \mathrm{~b}$ & $136.1 \pm 12.4 \mathrm{~cd}$ \\
\hline 50 & $6.5 \pm 0.05 b$ & $1.0 \pm 0.06 \mathrm{c}$ & $36.8 \pm 5.1 \mathrm{bc}$ & $27.6 \pm 1.3 b$ & $175.7 \pm 8.7 \mathrm{c}$ \\
\hline 75 & $7.0 \pm 0.02 \mathrm{a}$ & $1.3 \pm 0.05 b$ & $1.21 \pm 0.7 \mathrm{c}$ & $29.3 \pm 1.5 \mathrm{ab}$ & $261.6 \pm 10.6 b$ \\
\hline \multirow[t]{2}{*}{100} & $7.4 \pm 0.13 \mathrm{a}$ & $1.5 \pm 0.08 \mathrm{a}$ & $10.2 \pm 10.2 \mathrm{c}$ & $27.1 \pm 1.9 \mathrm{~b}$ & $330.5 \pm 23.2 \mathrm{a}$ \\
\hline & \multicolumn{5}{|c|}{ Tomato } \\
\hline 0 & $5.9 \pm 0.09 \mathrm{~d}$ & $1.1 \pm 0.10 \mathrm{a}$ & $5.9 \pm 2.1 \mathrm{NS}$ & $37.5 \pm 3.0 \mathrm{~b}$ & $21.3 \pm 2.7 \mathrm{~d}$ \\
\hline 25 & $6.3 \pm 0.05 c$ & $1.0 \pm 0.07 \mathrm{a}$ & $5.2 \pm 4.5$ & $50.2 \pm 5.1 \mathrm{a}$ & $45.6 \pm 9.1 \mathrm{~d}$ \\
\hline 50 & $6.8 \pm 0.03 b$ & $0.7 \pm 0.06 \mathrm{~b}$ & $<0.1 \pm 0$ & $26.8 \pm 1.4 \mathrm{c}$ & $77.3 \pm 4.6 \mathrm{c}$ \\
\hline 75 & $7.1 \pm 0.04 \mathrm{a}$ & $1.0 \pm 0.05 \mathrm{ab}$ & $<0.1 \pm 0$ & $25.1 \pm 1.3 \mathrm{c}$ & $200.0 \pm 8.7 b$ \\
\hline \multirow[t]{2}{*}{100} & $7.3 \pm 0.03 \mathrm{a}$ & $1.1 \pm 0.08 \mathrm{a}$ & $<0.1 \pm 0$ & $22.1 \pm 0.5 \mathrm{c}$ & $247.7 \pm 7.1 \mathrm{a}$ \\
\hline & \multicolumn{5}{|c|}{$\begin{array}{c}\text { Composted stover experiment } \\
\text { Marigold }\end{array}$} \\
\hline $0 \%$ Stover & $5.6 \pm 0.06 \mathrm{e}$ & $0.7 \pm 0.04 \mathrm{c}$ & $47.9 \pm 4.0 \mathrm{ab}$ & $8.11 \pm 0.5 \mathrm{c}$ & $36.7 \pm 2.5 \mathrm{~d}$ \\
\hline $25 \%$ Stover $^{\mathrm{y}}$ & $6.3 \pm 0.10 \mathrm{~d}$ & $0.7 \pm 0.06 \mathrm{c}$ & $14.7 \pm 2.8 b$ & $18.8 \pm 1.6 \mathrm{c}$ & $105.5 \pm 7.6 \mathrm{~d}$ \\
\hline $25 \%$ Distillers grain ${ }^{x}$ & $6.4 \pm 0.06 \mathrm{~d}$ & $2.0 \pm 0.12 b$ & $65.7 \pm 7.7 \mathrm{a}$ & $117.9 \pm 7.9 \mathrm{~b}$ & $257.9 \pm 16.0 \mathrm{c}$ \\
\hline $50 \%$ Quick compost $+\mathrm{CaO}^{\mathrm{w}}$ & $7.8 \pm 0.03 \mathrm{a}$ & $2.3 \pm 0.19 b$ & $77.2 \pm 13.4 \mathrm{a}$ & $22.7 \pm 0.6 \mathrm{c}$ & $415.2 \pm 31.6 b$ \\
\hline $50 \%$ Quick compost- $\mathrm{CaO}$ & $6.8 \pm 0.04 \mathrm{c}$ & $2.2 \pm 0.14 \mathrm{~b}$ & $53.3 \pm 8.4 \mathrm{a}$ & $143.5 \pm 8.4 b$ & $417.1 \pm 28.1 \mathrm{~b}$ \\
\hline \multirow[t]{2}{*}{$75 \%$ Quick compost-CaO } & $7.1 \pm 0.05 \mathrm{~b}$ & $3.6 \pm 0.22 \mathrm{a}$ & $76.3 \pm 14.2 \mathrm{a}$ & $232.6 \pm 16.4 \mathrm{a}$ & $820.0 \pm 60.9 \mathrm{a}$ \\
\hline & \multicolumn{5}{|c|}{ Tomato } \\
\hline $0 \%$ Stover & $5.5 \pm 0.08 \mathrm{f}$ & $1.1 \pm 0.08 \mathrm{~d}$ & $5.3 \pm 1.0 \mathrm{NS}$ & $13.8 \pm 0.6 \mathrm{~d}$ & $21.7 \pm 2.4 \mathrm{~d}$ \\
\hline $25 \%$ Stover $^{\mathrm{y}}$ & $6.4 \pm 0.06 \mathrm{~d}$ & $0.8 \pm 0.03 \mathrm{~d}$ & $<0.1 \pm 0$ & $21.2 \pm 0.9 \mathrm{~d}$ & $89.0 \pm 4.6 \mathrm{~d}$ \\
\hline $25 \%$ Distillers grain ${ }^{x}$ & $6.1 \pm 0.06 \mathrm{e}$ & $2.2 \pm 0.11 \mathrm{c}$ & $0.3 \pm 0.03$ & $144.4 \pm 9.5 \mathrm{c}$ & $192.5 \pm 23.7 \mathrm{c}$ \\
\hline $50 \%$ Quick compost $+\mathrm{CaO}^{\mathrm{w}}$ & $7.8 \pm 0.04 \mathrm{a}$ & $2.5 \pm 0.06 \mathrm{bc}$ & $<0.1 \pm 0$ & $30.8 \pm 1.4 \mathrm{~d}$ & $433.7 \pm 19.7 b$ \\
\hline $50 \%$ Quick compost-CaO & $6.8 \pm 0.03 \mathrm{c}$ & $2.6 \pm 0.10 b$ & $<0.1 \pm 0$ & $204.9 \pm 7.5 \mathrm{~b}$ & $435.0 \pm 14.9 \mathrm{~b}$ \\
\hline 75\% Quick compost-CaO & $7.3 \pm 0.04 b$ & $3.3 \pm 0.15 \mathrm{a}$ & $1.0 \pm 0.1$ & $243.8 \pm 13.2 \mathrm{a}$ & $687.3 \pm 33.0 \mathrm{a}$ \\
\hline
\end{tabular}

Mixes were sampled at the end of the experiment. Different letters within a plant species denote statistical differences among treatments $(P<0.05)$. NS $=$ nonsignificant.

${ }^{\mathrm{z}}$ Stover rate is the percentage of 0.94-mm ground stover added by volume to achieve 1:0:1 (peat:stover:perlite), 3:1:4, 2:2:4, 1:3:4, and 0:1:1.

${ }^{\mathrm{y}}$ The $0 \%$ and $25 \%$ stover rates were the same composition as in Expt. 1.

${ }^{\mathrm{x}}$ The $25 \%$ distillers grain was composed of $0.94-\mathrm{mm}$ sieved stover plus distillers grain, which was mixed at 3:1:4 (peat:PCS:perlite) to achieve a $25 \%$ rate.

${ }^{\text {w}}$ Quick compost stover comprised 0.94-mm sieved stover plus syrup with and without $\mathrm{CaO}$. The quick compost stover with $\mathrm{CaO}$ was mixed at 2:2:4 (peat:PCS: perlite) to achieve a $50 \%$ rate. The quick compost stover without Ca was mixed at 2:2:4 and 1:3:4 to achieve $50 \%$ and $75 \%$ rates.

Table 8. Influence of corn stover rate and composting when mixed with peat and perlite on water use and hydraulic properties of the mix under marigolds and tomatoes in two greenhouse experiments.

\begin{tabular}{|c|c|c|c|c|c|c|}
\hline Mix type & Bulk density $\left(\mathrm{g} \cdot \mathrm{cm}^{-3}\right)$ & Porosity (\%) & VWC at saturation (\%) & VWC at FC (\%) & VWC at PWP (\%) & AW (\%) \\
\hline Stover rate $(\%)^{z}$ & \multicolumn{6}{|c|}{$\begin{array}{c}\text { Corn stover rate experiment } \\
\text { Both species }\end{array}$} \\
\hline 0 & $0.12 \pm 0.0031 \mathrm{a}$ & $92.7 \pm 0.19 \mathrm{~b}$ & $83.1 \pm 0.10 \mathrm{NS}$ & $29.5 \pm 1.1 \mathrm{a}$ & $13.7 \pm 0.9 \mathrm{NS}$ & $15.7 \pm 1.4 \mathrm{a}$ \\
\hline 25 & $0.11 \pm 0.0024 \mathrm{ab}$ & $93.2 \pm 0.15 \mathrm{ab}$ & $82.5 \pm 0.92$ & $27.9 \pm 0.62 \mathrm{ab}$ & $12.7 \pm 0.5$ & $15.3 \pm 0.64 \mathrm{a}$ \\
\hline 75 & $0.10 \pm 0.0020 \mathrm{~b}$ & $93.6 \pm 0.12 \mathrm{a}$ & $83.4 \pm 0.83$ & $25.3 \pm 0.43 b$ & $12.2 \pm 0.6$ & $13.3 \pm 0.79 \mathrm{ab}$ \\
\hline 100 & $0.10 \pm 0.0018 \mathrm{~b}$ & $93.6 \pm 0.11 \mathrm{a}$ & $81.7 \pm 0.61$ & $24.8 \pm 0.57 \mathrm{~b}$ & $13.3 \pm 0.7$ & $11.5 \pm 0.81 \mathrm{~b}$ \\
\hline
\end{tabular}

\begin{tabular}{|c|c|c|c|c|c|c|}
\hline $0 \%$ Stover & $0.087 \pm 0.002 \mathrm{~d}$ & $94.6 \pm 0.12 \mathrm{a}$ & $81.5 \pm 1.2 \mathrm{a}$ & $27.3 \pm 1.0 \mathrm{NS}$ & $8.3 \pm 0.4 \mathrm{NS}$ & $17.4 \pm 0.9 \mathrm{NS}$ \\
\hline $25 \%$ Stover $^{y}$ & $0.089 \pm 0.0018 \mathrm{dc}$ & $94.5 \pm 0.11 \mathrm{ab}$ & $82.2 \pm 1.1 \mathrm{a}$ & $28.5 \pm 1.2$ & $7.4 \pm 0.6$ & $19.7 \pm 1.0$ \\
\hline $25 \%$ Distillers grain ${ }^{x}$ & $0.092 \pm 0.0026 \mathrm{bcd}$ & $94.3 \pm 0.16 \mathrm{abc}$ & $82.0 \pm 1.1 \mathrm{a}$ & $26.9 \pm 0.9$ & $8.6 \pm 0.6$ & $18.7 \pm 1.0$ \\
\hline $50 \%$ Quick compost $+\mathrm{CaO}^{\mathrm{w}}$ & $0.10 \pm 0.0017 \mathrm{a}$ & $93.7 \pm 0.11 \mathrm{~d}$ & $75.8 \pm 1.1 \mathrm{~b}$ & $19.4 \pm 6.9$ & $8.7 \pm 0.5$ & $17.2 \pm 0.9$ \\
\hline $50 \%$ Quick compost-CaO & $0.09 \pm 0.0024 \mathrm{ab}$ & $93.8 \pm 0.15 b c$ & $80.5 \pm 1.3 \mathrm{a}$ & $27.1 \pm 1.1$ & $9.5 \pm 0.7$ & $19.0 \pm 1.4$ \\
\hline $75 \%$ Quick compost-CaO & $0.096 \pm 0.0023 a b c$ & $94.0 \pm 0.14 \mathrm{bcd}$ & $80.1 \pm 0.7 \mathrm{ab}$ & $27.1 \pm 1.3$ & $8.4 \pm 0.4$ & $20.0 \pm 0.9$ \\
\hline
\end{tabular}

Different letters denote statistical differences among treatments $(P<0.05)$. NS $=$ nonsignificant; $\mathrm{VWC}=$ volumetric water content; FC $=$ field capacity; PWP $=$ permanent wilting point; $\mathrm{AW}=$ available water.

${ }^{\mathrm{z}}$ Stover rate is the percentage of $0.94-\mathrm{mm}$ ground stover added by volume to achieve 1:0:1 (peat:stover:perlite), 3:1:4, 2:2:4, 1:3:4, and 0:1:1.

${ }^{\mathrm{y}}$ The $0 \%$ and $25 \%$ stover rates were the same composition as in Expt. 1.

${ }^{\mathrm{x}}$ The $25 \%$ distillers grain was composed of $0.94-\mathrm{mm}$ sieved stover plus distillers grain, which was mixed at 3:1:4 (peat:PCS:perlite) to achieve a $25 \%$ rate.

${ }^{\text {w }}$ Quick compost stover comprised 0.94-mm sieved stover plus syrup with and without $\mathrm{CaO}$. The quick compost stover with $\mathrm{CaO}$ was mixed at 2:2:4 (peat:PCS: perlite) to achieve a $50 \%$ rate. The quick compost stover without Ca was mixed at 2:2:4 and 1:3:4 to achieve $50 \%$ and $75 \%$ rates.

those mixes are not suitable for greenhouse mixes.

The improved plant performance with the addition of $25 \%$ distillers grain indicated that additional processing may improve the suit- ability of corn stover as a component of soilless mixes. Peat is composed of partially decomposed bog plants; therefore, processing peat alternatives to hasten the decomposition process may allow the peat alternatives to support plant growth similar to peat through the reduction of nutrient immobilization.

Previous studies that evaluated composted or processed alternatives to peat showed positive or neutral effects of the alternatives 

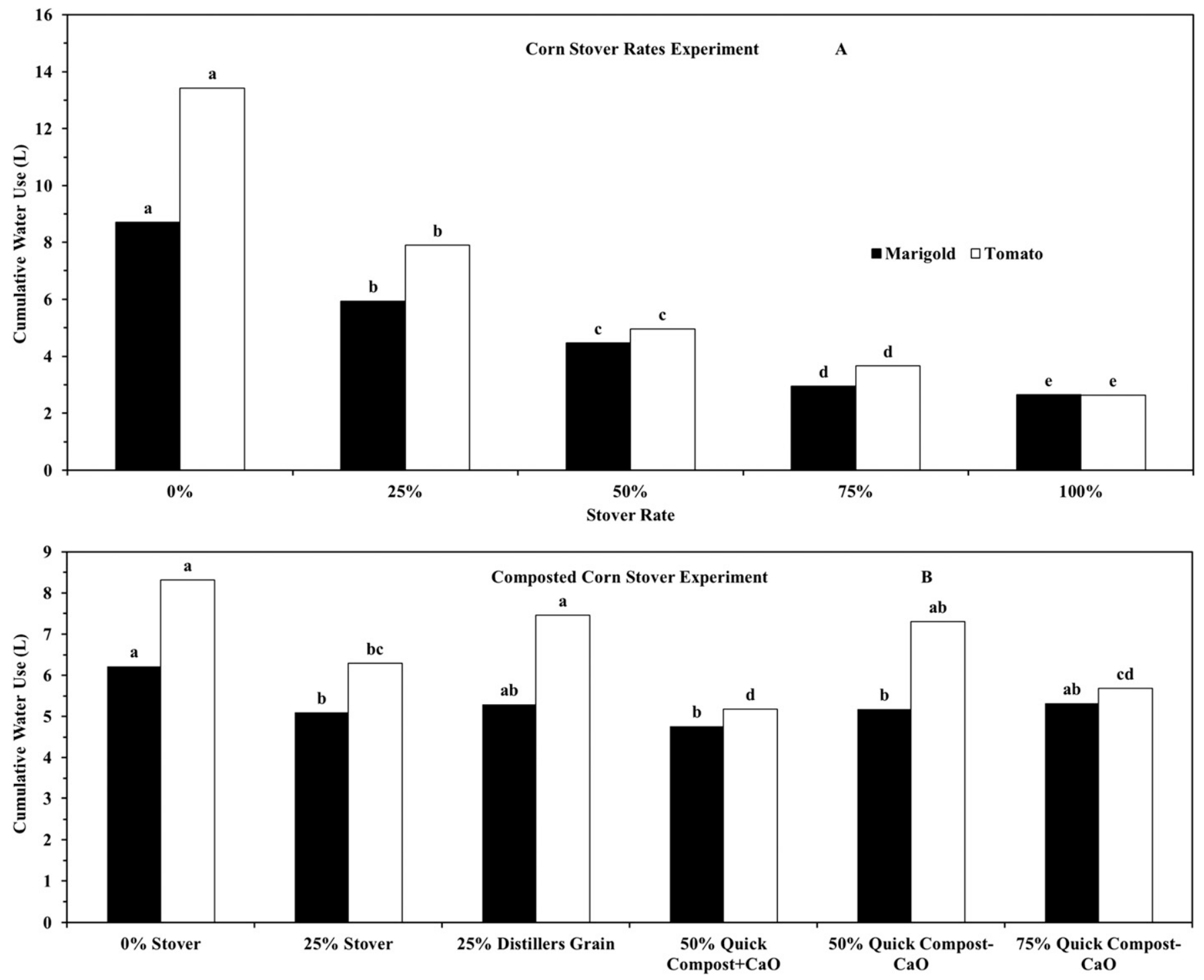

Fig. 2. Cumulative water use with different rates of corn stover additions to peat (A) and rate and type of composted corn stover additions to peat (B). Different letters within a plant species denote statistical differences among treatments. Stover rate is the percentage of 0.94-mm ground stover added by volume to achieve 1:0:1 (peat:stover:perlite), 3:1:4, 2:2:4, 1:3:4, and 0:1:1. Quick compost stover comprised 0.94-mm sieved stover plus syrup with and without CaO. The $50 \%$ quick compost stover with $\mathrm{CaO}$ was mixed at 2:2:4 (peat:PCS:perlite). The $50 \%$ and $75 \%$ quick compost stover without $\mathrm{Ca}$ was mixed at 2:2:4 and 1:3:4. The $25 \%$ distillers grain was composed of $0.94-\mathrm{mm}$ sieved stover plus distillers grain, which was mixed at 3:1:4 (peat:PCS:perlite). The $0 \%$ and $25 \%$ stover rates were mixed as per the stover rate experiment.

on plant growth (Margenot et al., 2018; Vaughn et al., 2013). In one study, up to $15 \%$ woodchip or straw biochars increased tomato and marigold plant heights compared with peat (Vaughn et al., 2013). Margenot et al. (2018) assessed flower numbers and biomass yields for marigolds grown under different rates of biochar and found no differences in either parameter due to biochar rate; however, relative greenness increased with biochar.

Other studies that investigated processed or composted alternatives to peat found differences in physical and chemical properties when peat alternatives were included at rates $\geq 50 \%$ (Alvarez et al., 2017; Massa et al., 2018; Vaughn et al., 2013). For example, the use of composts at inclusion rates up to $70 \%$ increased mix $\mathrm{pH}$ and $\mathrm{EC}$ relative to peat, but composts generally improved plant growth (Massa et al., 2018).
The use of wood or straw biochars at rates $<50 \%$ increased bulk density, $\mathrm{pH}$, and $\mathrm{EC}$, but reduced porosity, thus leading to generally taller tomatoes and marigolds; however, their use led to similar biomass yields compared with peat (Vaughn et al., 2013). Alvarez et al. (2017) showed that although $50 \%$ biosolids hydrochar and biochar from urban wastes may increase mix $\mathrm{pH}$ and $\mathrm{N}$ and $\mathrm{K}$ concentrations and decrease $\mathrm{P}$ concentrations, the growth of perennial ryegrass (Lolium perenne L.) was similar to or greater than that grown in peat alone.

\section{Conclusions}

This study suggests that some composted stover mixes and low amounts of processed corn stover can support plant growth because they have properties similar to those of peat.
High rates of stover additions ( $\geq 50 \%$ ) generally reduced plant growth and quality parameters (relative greenness, flower numbers, biomass yield), thus leading to small plants with few flowers. As the stover rate increased, plant height and vegetative and reproductive biomass yields decreased. Our results suggest that $25 \%$ stover ( 3 peat: 1 PCS: 4 perlite) addition may produce plants with size and greenness similar to those grown in mixes without stover. The decrease in plant growth with increased stover addition were most likely due to the lower tissue $\mathrm{N}$ and $\mathrm{P}$ concentrations and available water in mixes with high rates of stover. This indicates that high rates of stover additions had large negative effects on changes in the physical and chemical characteristics relative to the commonly used mix (peat). Results from the composted stover experiment suggest that the 

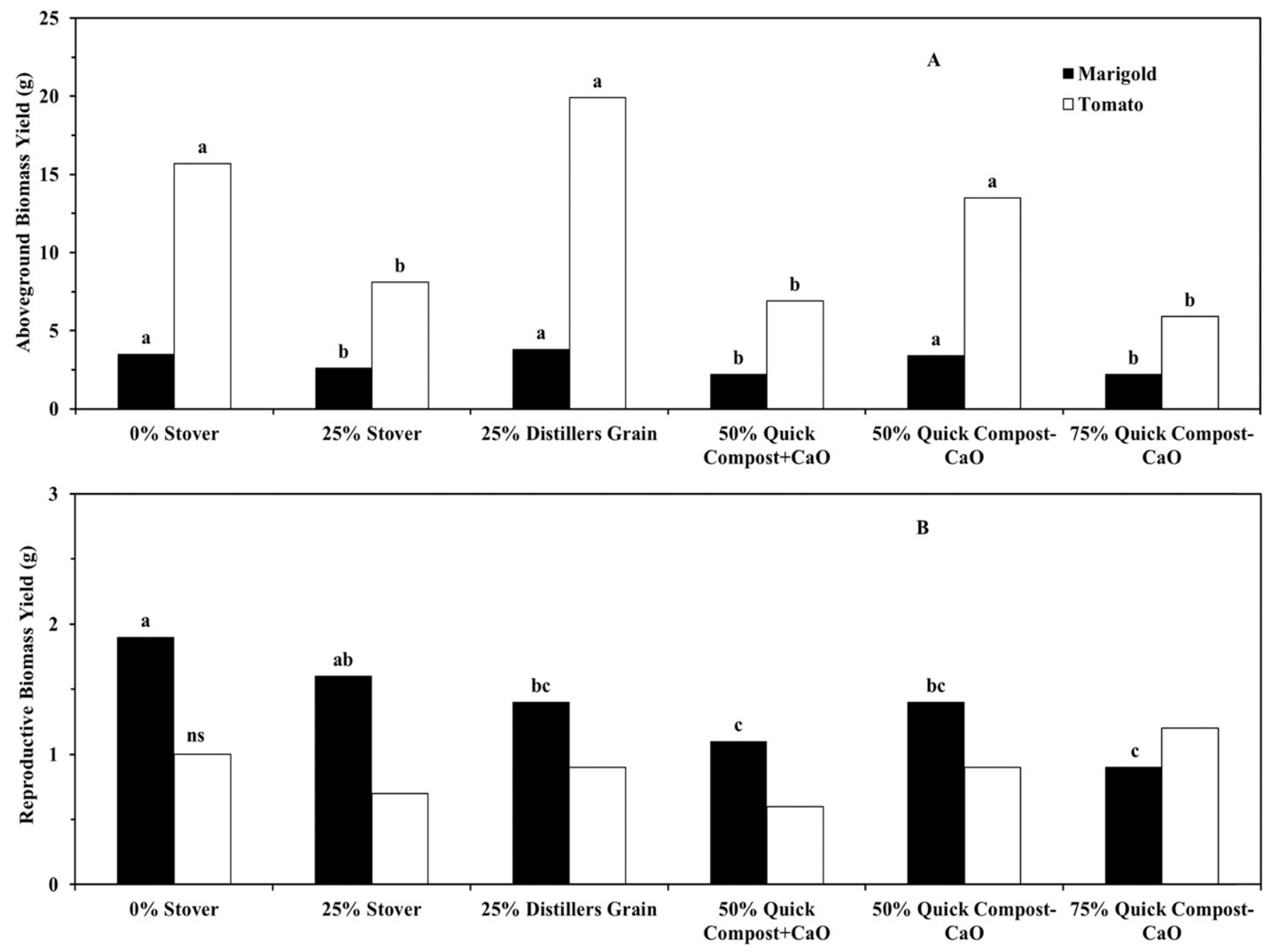

Fig. 3. Influence of the corn stover rate and composted corn stover additions to peat on the marigold aboveground biomass yield (A) and reproductive biomass yield (B) of marigold and tomatoes. Different letters within a plant species denote statistical differences among treatments. Quick compost stover comprised 0.94-mm sieved stover plus syrup with and without $\mathrm{CaO}$. The 50\% quick compost stover with $\mathrm{CaO}$ was mixed at 2:2:4 (peat:PCS:perlite). The 50\% and 75\% quick compost stover without $C$ a was mixed at 2:2:4 and 1:3:4. The $25 \%$ distillers grain was composed of 0.94-mm sieved stover plus distillers grain, which was mixed at 3:1:4 (peat:PCS:perlite). The $0 \%$ and $25 \%$ stover rates were mixed as per the stover rates experiment.

addition of $25 \%$ distillers grain (3 peat: 1 PCS: 4 perlite), $25 \%$ stover (3 peat: 1 PCS: 4 perlite), and $0 \%$ stover (1:1 perlite) produced plants with size and greenness similar to those of plants grown in peat due to the relatively similar chemical and physical characteristics among these three composted treatments and peat alone. The quick composted stover resulted in some of the smallest plants likely due the higher $\mathrm{pH}$ and $\mathrm{EC}$ values compared with those of peat. Overall, the addition of $25 \%$ distillers grain (3 peat: 1 distillers grain: 4 perlite) and $25 \%$ stover ( 3 peat: 1 stover: 4 perlite) showed the most promise as additives to peat-based greenhouse mixes.

\section{Literature Cited}

Alvarez, M.L., G. Gasco, C. Plaza, J. Paz-Ferreiro, and A. Mendez. 2017. Hydrochars from biosolids and urban wastes as substitute materials for peat. Land Degrad. Dev. 28:2268-2276.

Abad, M., P. Noguera, R. Puchades, A. Maquieira, and V. Noguera. 2002. Physico-chemical and chemical properties of some coconut coir dusts for use as a peat substitute for containerised ornamental plants. Bioresour. Technol. 82: 241-245.

Barrett, G.E., P.D. Alexander, J.S. Robinson, and N.C. Bragg. 2016. Achieving environmentally sustainable growing media for soilless plant cultivation systems - A review. Scientia Hort. 212:220-234.

Blake, G.R. and K.H. Hartge. 1986. Bulk density, p. 363-375. Methods of soil analysis: Part 1. SSSA Book Ser. 5. SSSA, Madison, WI.

Blanco-Canqui, H. and R. Lal. 2009. Crop residue removal impacts on soil productivity and environmental quality. Crit. Rev. Plant Sci. 28:139163.

Buck, J.S. and M.R. Evans. 2010. Physical properties of ground parboiled fresh rice hulls used as a horticultural root substrate. HortScience 45:643-649.

Dane, J.H. and J.H. Hopmans. 2002. Water retention and storage, p. 671-717. In: J.H. Dane and G.C. Topp (eds.). Methods of soil analysis. Part 4. Agron. Monogr. 5. SSSA, Madison, WI.

Graham, R.L., R. Nelson, J. Sheehan, R.D. Perlack, and L.L. Wright. 2007. Current and potential US corn stover supplies. Agron. J. 99:1-11.

Helrich, K. 1990. Official methods of analysis of the association of official analytical chemists.
Association of Official Analytical Chemists, Inc, Arlington, VA.

Juckers, M. and S.A. Watmough. 2014. Impacts of simulated drought on pore water chemistry of peatlands. Environ. Pollut. 184:73-80.

Margenot, A.J., D.E. Griffin, B.S.Q. Alves, D.A. Rippner, C. Li, and S.J. Parikh. 2018. Substitution of peat moss with softwood biochar for soil-free marigold growth. Ind. Crops Prod. 112:160-169.

Massa, D., F. Malorgio, S. Lazzereschi, G. Carmassi, D. Prisa, and G. Burchi. 2018. Evaluation of two green composts for peat substitution in geranium (Pelargonium zonale L.) cultivation: Effect on plant growth, quality, nutrition, and photosynthesis. Scientia Hort. 228: 213-221.

Peterson, S.C. and M.A. Jackson. 2014. Simplifying pyrolysis: Using gasification to produce corn stover and wheat straw biochar for sorptive and horticultural media. Ind. Crops Prod. 53:228-235.

SAS Institute. 2018. SAS OnlineDoc 9.1.3. SAS Inst., Cary, NC. 22 May 2018. <support.sas. com/onlinedoc/913/docMainpage.jsp $>$.

Sambo, P., F. Sannazzaro, and M.R. Evans. 2008 Physical properties of ground fresh rice hulls and sphagnum peat used for greenhouse root substrates. HortTechnology 18:384-388. 
Schwarzer, C., T. Heinken, V. Luthardt, and J. Joshi. 2013. Latitudinal shifts in species interactions interfere with resistance of southern but not of northern bog-plant communities to experimental climate change. J. Ecol. 101:1484-1497.

Shanan, N.T., E.I. El-Dardiry, and M.A. El-Hady. 2016. Impact of peanut shell mixed with peat moss as an improved medium and its effect on growth characters of Petunia. Acta Hort. 1146:191-198.

Suo, L., X. Sun, and W. Jiang. 2013. Effect of pretreatment on biomass residue structure and the application of pyrolysed and composted biomass residues in soilless culture. PLoS One 8:e64550.
USDA-NASS. 2017. Statistics by subject. National statistics for corn. 2 Mar. 2017. <https://www. nass.usda.gov/Statistics_by_Subject>.

Vaughn, S.F., N.A. Deppe, D.E. Palmquist, and M.A. Berhow. 2011. Extracted sweet corn tassels as a renewable alternative to peat in greenhouse substrates. Ind. Crops Prod. 33: 514-517.

Vaughn, S.F., J.A. Kenar, A.R. Thompson, and S.C. Peterson. 2013. Comparison of biochars derived from wood pellets and pelletized wheat straw as replacements for peat in potting substrates. Ind. Crops Prod. 51:437-443.

Warncke, D. 1998. Greenhouse root media, p. 61-64. In: J.R. Brown (ed.). Recommended chemical soil test procedures for the North Central Region. North Central Regional Publication No. 221 (revised). University of Missouri Ag. Expt. Station, Columbia, MO

Xiong, J., Y. Tian, J. Wang, W. Liu, and Q. Chen. 2017. Comparison of coconut coir, rockwool, and peat cultivations for tomato production: Nutrient balance, plant growth, and fruit quality. Front. Plant Sci. 8:1327.

Zhao, G., B.A. Bryan, D. King, Z. Luo, E. Wang, and Q. Yu. 2015. Sustainable limits to crop residue harvest for bioenergy: Maintaining soil carbon in Australia's agricultural lands. Glob. Change Biol. Bioenergy 7:479-487. 